Current Opinion in Immunology

Manuscript Number: COIMMU-D-16-00049

Article Title: NK cells in host responses to viral infections

Authors: Viola C. Lam ${ }^{1,2}$ and Lewis L. Lanier ${ }^{2,3}$

${ }^{1}$ Biomedical Sciences Graduate Program, San Francisco, CA 94143, United States

${ }^{2}$ Department of Microbiology and Immunology, University of California, San Francisco, CA

94143, United States

${ }^{3}$ Parker Institute for Cancer Immunotherapy, San Francisco, CA 94129, United States

Corresponding author:

Lewis L. Lanier

Lewis.Lanier@ucsf.edu 


\begin{abstract}
$\underline{\text { Abstract }}$
Natural killer (NK) cells are cytotoxic innate lymphocytes that play an important role in viral clearance. NK cell responses to viral infections were originally believed to be non-specific and lacked immune memory recall responses. It is now appreciated that NK cell responses to viral infections can be specific and in some cases memory recall responses are established. Increasing evidence also illuminates the complexity of NK cell interactions with both innate and adaptive immune cells. Here, we summarize the evidence for NK cell-specific memory responses to viral infections and the intricate reciprocal interactions between NK cells and other immune cells that dictate their activation and effector functions.
\end{abstract}

\title{
Introduction
}

Natural killer (NK) cells are innate lymphocytes that play an integral role in the host's immune defense against pathogens. NK cells have the unique ability to recognize and lyse target cells without prior exposure. Patients with genetic mutations resulting in diminished NK cell numbers or function succumb to recurrent herpesvirus, varicella virus, and papillomavirus infections [1][4], highlighting the importance of NK cells in controlling certain viral infections. NK cell responses were believed to be non-specific due to expression of germ-line encoded receptors that do not recombine to generate antigen-specific receptors like $\mathrm{T}$ and $\mathrm{B}$ cells [5]. It was thought that NK cells served to control viral burden by broadly lysing virus-infected cells until the adaptive immune system developed specific anti-viral responses. However, NK cell responses can be specific and they interact with both innate and adaptive immune cells to coordinate appropriate anti-viral responses [reviewed in 6 and 7]. Here we summarize recent findings of NK cell 
specificity through the generation of long-lived memory cells and how NK cells coordinate an anti-viral response with other immune cells.

\section{NK cell Memory}

Immunological memory responses are the basis for vaccination and protect the host from secondary encounters with lethal and recurring pathogens. The memory T and B lymphocytes of the adaptive immune system are highly specific and provide quick and robust defenses. These memory response characteristics are now attributed to NK cells in certain situations. First appreciated in studies of delayed contact hypersensitivity, NK cells displaying properties of memory have been demonstrated in response to alloantigens and infectious agents, during homeostatic proliferation, and can be elicited by cytokine stimulation [8]-[11], [12**], [13]. Molecular mechanisms governing the generation of memory NK cells are beyond the scope of this article and are reviewed elsewhere [6], [7], [14].

Viral infections induce the generation of memory cells in the T, B, and now NK cell populations. Studies of mouse cytomegalovirus (MCMV) infection identified a subset of $\mathrm{Ly}_{4} 9 \mathrm{H}^{+}$ NK cells in C57BL/6 mice that specifically recognize the MCMV-encoded glycoprotein m157 [15]-[17]. In 2009, Sun et al. [13] reported the expansion, contraction, and persistence of Ly49H ${ }^{+} \mathrm{NK}$ cells after MCMV infection (Figure 1a). These cells conferred specific protection against MCMV re-challenge and not other heterologous infections, indicating that these are MCMV-specific memory NK cells [13], [18**]. The Ly49H-m157 interaction is crucial for host control of MCMV infection. Infection with $\mathrm{MCMV}^{\mathrm{G} 1 \mathrm{~F}}$, a strain in which a m157 variant recognizes both the activating Ly49H and the inhibitory Ly49C receptor, rendered mice more susceptible to low dose infection. Ly49C competed for m157 binding and diminished Ly49H- 
mediated activation by destabilizing NK cell-MCMV-infected target cell contact. However, cisinteractions of Ly49C with major histocompatibility complex class I (MHC-I) expressed on the NK cells restricted binding of Ly49C to m157 on MCMV-infected cells, thus allowing sufficient Ly49H-mediated activation to provide for limited host protection [19**], [20**]. A recent study reported that $50 \%$ of $\mathrm{Ly} 49 \mathrm{H}^{+} \mathrm{NK}$ cells in C57BL/6 mice co-express the inhibitory receptor NKR-P1B. Expression of NKR-P1B inhibited the proliferation and protection of $\mathrm{Ly}_{4} 4 \mathrm{H}^{+}$cells during MCMV infection, but did not alter secretion of interferon- $\gamma$ (IFN- $\gamma)$ and granzymes [21**]. It is unknown whether NKR-P1B expression affects the generation of $\mathrm{Ly}_{4} 9 \mathrm{H}^{+}$memory NK cells, although this seems likely. Additionally, animal models of herpes simplex virus, influenza, and simian immunodeficiency virus infection also revealed the existence of memory NK cells. In these studies, NK cells previously exposed to viral antigens conferred enhanced IFN- $\gamma$ production, cytotoxicity, and protection upon re-challenge [9], [22]-[24], [25*], [26]. The ligand and NK cell receptor(s) responsible for protection against these viruses (other than MCMV) are unknown and identifying them will give scientists insight into controlling these viral infections in humans.

Many investigators have also identified a potential pool of memory NK cells in humans. Gumá et al. first reported the expansion and persistence of $\mathrm{CD} 94^{+} \mathrm{NKG} 2 \mathrm{C}^{+} \mathrm{NK}$ cells in human CMV-seropositive, but not in HCMV-seronegative, individuals [27]-[29]. Other investigators have also described the expansion of $\mathrm{NKG}_{2} \mathrm{C}^{+} \mathrm{NK}$ cells in chikungunya, hepatitis $\mathrm{B}$ and $\mathrm{C}$, Epstein-Barr (EBV), and hanta virus infections [30]-[33]. However, individuals in these studies were also infected with $\mathrm{HCMV}$, so expansion of the $\mathrm{NKG} 2 \mathrm{C}^{+} \mathrm{NK}$ cells likely resulted from subclinical reactivation of HCMV in these patients. Emerging evidence has elucidated the specificity of $\mathrm{NKG}_{2} \mathrm{C}^{+} \mathrm{NK}$ cell expansion in response to HCMV infection. Björkström et al. did 
not observe expansion of $\mathrm{NKG}_{2} \mathrm{C}^{+} \mathrm{NK}$ cells or any particular $\mathrm{NK}$ cell subset during recurrent herpes simplex virus-2 infection [34] and Hendricks et al. found that acute EBV infection in HCMV-seropositive and seronegative individuals did not induce expansion of $\mathrm{NKG}^{+} \mathrm{C}^{+} \mathrm{NK}$ cells [35**]. Both studies indicate that the expansion of $\mathrm{NKG}^{+} \mathrm{C}^{+} \mathrm{NK}$ cells is specific to $\mathrm{HCMV}$ and not HSV or EBV infections. Degranulation of $\mathrm{NKG}_{2} \mathrm{C}^{+} \mathrm{NK}$ cells is triggered by co-culture with HCMV-infected primary human endothelial cells but not HCMV-infected fibroblasts or monocyte-derived dendritic cells $\left[36^{*}\right]$. Further, NK cell expansion is dependent on expression of the NKG2C ligand, HLA-E, on the infected cells and interleukin (IL)-12 produced by myeloid cells (Figure 1b) [37]. Interestingly, HMCV-seropositive individuals possessing a homozygous null allele of $K L R C 2$ (the gene encoding NKG2C) remain asymptotic and healthy, suggesting that NK cells possess redundant pathways in response to HCMV. In these individuals, the adaptive (or memory) NK cells (defined as FceRI $\gamma^{-}$and/or Syk ${ }^{-}$) expressed elevated levels of CD2, which synergized with CD16 to activate NK cells in HCMV infection [38**]. Binding of CD2 to CD58, upregulated on HCMV-infected fibroblasts, is critical to induce CD16-dependent antibody-mediated activation of $\mathrm{NKG}_{2} \mathrm{C}^{+} \mathrm{NK}$ cells (Figure 1c) [39**]. Further insight into $\mathrm{NKG} 2 \mathrm{C}^{+} \mathrm{NK}$ cells are described in a recent review by Rölle and Brodin [40].

\section{Modulation of the Innate Immune Response}

NK cells participate in complex interactions with neutrophils, macrophages, and dendritic cells during viral infections. The appreciation of NK cell interactions with neutrophils has emerged in the past decade with reports describing multiple factors regulating mutual maturation, activation, and effector functions [41], [42]. In vitro co-culture experiments with human NK cells revealed that IL-15- or IL-18-activated NK cells modulated neutrophil activation and survival via IFN- $\gamma$ 
and granulocyte macrophage colony-stimulating factor (GM-CSF) to perpetuate an immune response [43]. Alternatively, human NK cells may induce neutrophil apoptosis via NKp46 and Fas-dependent mechanisms to limit inflammation and further activation of immune responses [44]. In mouse models, IL-22 production by CD3`NK1.1 ${ }^{+}$(possibly NK cells, but more likely type 3 innate lymphocytes), $\mathrm{CD}^{+} \mathrm{NK} 1.1^{+}$, and $\mathrm{T}$ cells was necessary for neutrophil recruitment to MCMV-infected tissues to control acute infection [45]. Reciprocally, neutrophils modulate NK cell maturation, activation, function, homeostasis, cytokine production, and NK cell licensing [46], [47**], [48*], [49*].

Macrophages secrete cytokines and express ligands to modulate NK cell responses during viral infections [50]. NK cells can readily kill virus-infected macrophages to limit viral burden, as well as cytokines that these virus-infected macrophages secrete. Romo et al. found that M1 macrophages were more resistant to HCMV infection than M2 macrophages. M1 macrophages secreted inflammatory cytokines that triggered autologous NK cells to produce IFN- $\gamma$, whereas M2 macrophages produced limited cytokines and did not induce robust NK cell responses [51], [52]. Another study found that inflammatory monocytes and NK cells contribute to MCMV control via CD155 and DNAM-1 interactions. The MCMV-encoded protein m20.1 induced downregulation of CD155 in infected monocytes to evade immune detection by the DNAM-1 activating receptor on NK cells [53**]. Furthermore, Quillay et al. described inhibition of human immunodeficiency virus (HIV)-1 infection in the decidua during the first trimester of pregnancy. Decidua NK cells prevented the establishment of HIV-1 infection of decidua macrophages in a cell-contact and unknown soluble factor-dependent mechanism [54*]. The intricate cross talk between macrophages and NK cells served to modulate anti-viral immune responses. 
Dendritic cells (DC) are potent antigen-presenting cells that initiate the adaptive immune response. NK cells interact with DCs to reciprocally activate and influence subsequent effector functions [55]-[59]. NK cells are recruited to secondary lymphoid organs to assist in modulating the adaptive immune response [60]-[62*]. In vitro IL-2-activated human NK cells induced DC maturation and increased their ability to activate and polarize naïve $\mathrm{CD} 4^{+} \mathrm{T}$ cells. These polarized $\mathrm{CD} 4^{+} \mathrm{T}$ cells potently increased their ability to induce antigen-specific cytotoxic $\mathrm{CD} 8^{+}$ T cell responses [63], [64]. Reciprocally, activated DCs increased NK cell production of IFN- $\gamma$ and tumor necrosis factor (TNF), which further induced DC maturation in a cell contactdependent manner [65], [66].

DC-NK cell interactions vary between different viral infections. In vitro and in vivo systemic HSV infection revealed that inflammatory cytokines such as IFN- $\alpha$ and TNF- $\alpha$ from DCs promote NK cell degranulation and IFN- $\gamma$ production [67**], [68]. Engagement of the activating receptor, NKG2D, on NK cells and NKG2D ligands induced on DCs by IL-18 were important for NK cell activation in vaccinia infection, whereas IL-15 from DCs and NKG2D engagement on NK cells were necessary for HIV-specific priming and control of infection in $\mathrm{CD}^{+} \mathrm{T}$ cells [69*], [70*]. Additionally, DCs stimulated with HIV-1 Gag-virus-like particles induced robust antigen-specific NK cell proliferation, IFN- $\gamma$ production, and cytotoxicity against HIV-1-infected $\mathrm{CD}^{+} \mathrm{T}$ cells [71]. Immune responses are dampened by NK cell-mediated lysis of DCs by limiting viral load and activation of the adaptive immune response. DCs activated by different toll-like receptor ligands upregulated expression of CD155 and CD112, which bind to DNAM-1 on NK cells to induce cytolysis of immature and mature DCs [72]. GM-CSF treatment of DC upregulates CD155 and ICAM-1, which can induce NK cell-mediated lysis of DCs [73*]. 
NK cells lysed HSV-2 and Dengue virus-infected DCs because expression of HLA class I molecules were downregulated [74], [75*].

Certain DC-NK cell interactions favor viral persistence and immune escape. Patients with chronic hepatitis B infection have elevated DC activation, but failed to induce NK cell cytotoxicity in co-culture systems [76], [77]. In MCMV infection, IL-10 produced by DCs suppressed DC-NK cell crosstalk, which impaired MCMV-specific $\mathrm{CD}^{+}{ }^{+} \mathrm{T}$ cell priming and supported viral latency [78]. Of note, HIV opsonized by complement and antibody altered DC cytokine and chemokine responses, which resulted in decreased recruitment of NK cells to the mucosa to control initial HIV infection [79**]. This may result in the poor activation of the adaptive immune response against HIV, which highlights the importance of DC-NK cell responses in controlling viral burden and anti-viral $\mathrm{T}$ cell responses. Table 1 lists detailed interactions between NK cells and innate cells mentioned in this review.

\section{Modulation of the Adaptive Immune Response}

Besides indirectly modulating adaptive immune responses by limiting or perpetuating recruitment and cytokine production of innate immune cells, NK cells can directly control antiviral T cell responses [80]-[82]. Study of persistent lymphocytic choriomeningitis virus (LCMV) infection in mice revealed that viral inoculum doses dictated host NK cell responses. At medium viral doses, NK cells facilitated fatal pathology by lysing activated $\mathrm{CD}^{+}{ }^{+} \mathrm{T}$ cells, thereby promoting higher viral burden, $\mathrm{CD}^{+} \mathrm{T}$ cell exhaustion, and subsequent death of the host. Conversely at high viral doses, NK cells prevented fatal pathology by limiting excessive CD4 ${ }^{+}$ and $\mathrm{CD}^{+} \mathrm{T}$ cell responses, allowing viral persistence, and survival of the host [83], [84*]. In these studies, NK cells altered the cytokine milieu and the polarization of $\mathrm{T}$ cell responses. 
Furthermore, chronic LCMV infection impairs the development of memory $\mathrm{CD} 8^{+} \mathrm{T}$ cells [85*]. Conversely, depletion of NK cells results in increased antigen presentation, $\mathrm{CD} 4^{+} \mathrm{T}$ cell expansion, improved $\mathrm{CD} 8^{+} \mathrm{T}$ cell responses, elevated numbers of follicular helper $\mathrm{T}$ cells, and antibody responses, suggesting that NK cells have dual roles in anti-viral responses [86], [87**], [88*].

A similar phenomenon is observed in influenza infection. In one study, mice infected with a sublethal dose of influenza revealed that NK cells were beneficial. IFN- $\gamma$ produced by NK cells enhanced DC migration and T cell recruitment to the draining lymph node. NK cell depletion significantly diminished the generation of flu-specific T cells [89]. However, another report suggests that NK cells are detrimental to lethal doses of influenza. Depletion of NK cells resulted in reduced recruitment of innate cells, inflammatory cytokines, and lung pathology [90]. Both models of viral infections suggest that NK cells may have dual functions in modulating the adaptive system.

Emerging evidence suggests that NK-T cell interactions are more complicated than originally perceived. Human NK cells cultured with UV-inactivated HSV-1 and HSV-2 upregulated expression of HLA-DQ and HLA-DR and formed immunological synapses with autologous $\mathrm{CD}^{+} \mathrm{T}$ cells. This interaction induced $\mathrm{CD} 4^{+} \mathrm{T}$ cell activation and IFN- $\gamma$ production [91]. In another study, IL-21 induced expansion of HLA-DR ${ }^{+}$CD86 ${ }^{+}$NKp44- NK cells, which enhanced the development of central memory $\mathrm{CD} 4^{+} \mathrm{T}$ cells [92**]. Furthermore, $\mathrm{CD} 4^{+} \mathrm{T}$ cell depletion or IL-2 neutralization in macaque SIV-controllers decreased NK cell activation and cytokine production. Interestingly, anti-retroviral therapy in SIV-non-controllers re-established NK cell activation and cytokine production, suggesting that $\mathrm{NK}$ cells and $\mathrm{CD} 4^{+} \mathrm{T}$ cells cooperate to control SIV infection [93]. A recent study found that HLA-F binding to the activating 
receptor, KIR3DS1, induces NK cell degranulation and cytokine production. $\mathrm{KIR}_{3 \mathrm{DS}}{ }^{+} \mathrm{NK}$ cells suppressed viral replication of HIV-1-infected autologous human CD4 ${ }^{+} \mathrm{T}$ cells, which had upregulated HLA-F expression [94**].

NK cells indirectly modulate $\mathrm{CD}^{+} \mathrm{T}$ cell responses. MCMV infection with a strain lacking m157 expression abolishes $\mathrm{Ly} 49 \mathrm{H}^{+} \mathrm{NK}$ cell recognition and initial viral control. Mice infected with a low dose of the m157-deficient MCMV demonstrated increased viral load, early DC maturation, and elevated amounts of pro-inflammatory cytokines, which resulted in an enhanced early $\mathrm{CD}^{+} \mathrm{T}$ cell response [95]. Conversely, a mouse model of hepatitis B (HBV) infection revealed a positive correlation between $\mathrm{HBV}$-specific $\mathrm{CD} 8^{+} \mathrm{T}$ cells and $\mathrm{NK}$ cells. Depletion of NK cells resulted in diminished $\mathrm{CD}^{+} \mathrm{T}$ cell frequencies and adoptive transfer of HBV-exposed NK cells was sufficient to restore $\mathrm{CD}^{+} \mathrm{T}$ cell function [96*]. However, it is unclear whether $\mathrm{CD}^{+} \mathrm{T}$ cells and DCs participate in coordinating $\mathrm{NK}$ cell and CD8 ${ }^{+} \mathrm{T}$ cell responses in this model. In humans, a study revealed that the elderly have increased percentages of both $\mathrm{NKG} 2 \mathrm{C}^{+} \mathrm{NK}$ cells and $\mathrm{CD}^{+} \mathrm{T}$ cells in response to HCMV infection compared with the young [97*], suggesting that NK cells may tune the $\mathrm{CD}^{+} \mathrm{T}$ cell responses to complement their control of viral burden.

\section{Concluding Remarks}

NK cells provide immune protection from different viral infections. Evidence in animal models and human studies indicate that NK cells can develop long -lasting antigen-specific memory cells. Identification of the viral antigens and the NK cell receptor(s) responsible for many of these functions remain to be determined. Although specific NK cell responses depend on viral context, they generally require other cells to coordinate effective anti-viral responses (Figure 2). 
NK cells interact with neutrophils, macrophages, and dendritic cells to regulate the cytokine milieu, initial viral load, and $\mathrm{CD}^{+}{ }^{+} \mathrm{T}$ cell responses. NK cells also directly limit $\mathrm{CD}^{+} \mathrm{T}$ cells and their effects on $\mathrm{CD}^{+} \mathrm{T}$ cells. Much more needs to be understood to fully grasp how NK cells respond to viral infections.

\section{$\underline{\text { Acknowledgements }}$}

We thank the Lanier laboratory for helpful comments and discussions. We apologize to those whose work we were unable to discuss due to space limitations. VCL is supported by the Graduate Research Fellowship from the National Science Foundation. LLL is supported by National Institutes of Health grant AI068129 and the Parker Institute for Cancer Immunotherapy. LLL is an American Cancer Society Professor.

\section{Figure 1: Expansion of NK cells in cytomegalovirus infection}

Ly49H-m157 interaction in MCMV infection (A) and CD94-NKG2C and HLA-E interaction in HCMV infection (B) induces NK cell production of IFN- $\gamma$ and lysis of target cell. NK cells persist as memory cells. (C) Synergy of CD2 and CD16 for effective antibody-dependent cellmediated cytotoxicity (ADCC) of HCMV-infected cells in $K L R C 2^{-/-}$humans.

\section{Figure 2: NK cell interactions and their effects on other immune cells}

NK cells modulate other immune cells to coordinate anti-viral immune responses. Interactions with neutrophils, macrophages, monocytes, and dendritic cells results in mutual activation or NK cell-mediated lysis to limit responses. NK cells directly or indirectly modulate CD $4^{+}$and $\mathrm{CD} 8^{+} \mathrm{T}$ cell responses. 


\section{$\underline{\text { References }}$}

[1] Biron CA, Byron KS, and Sullivan JL: Severe herpesvirus infections in an adolescent without natural killer cells. $N$ Engl J Med 1989, 320:1731-1735.

[2] Notarangelo LD and Mazzolari E: Natural killer cell deficiencies and severe varicella infection. $J$ Pediatr 2006, 148:563-564.

[3] Orange JS: Human natural killer cell deficiencies and susceptibility to infection. Microbes Infect Inst Pasteur 2002, 4:1545-1558.

[4] Mace EM, Hsu AP, Monaco-Shawver L, Makedonas G, Rosen JB, Dropulic L, Cohen JI, Frenkel EP, Bagwell JC, Sullivan JL, et al.: Mutations in GATA2 cause human NK cell deficiency with specific loss of the CD56(bright) subset. Blood 2013, 121:2669-2677.

[5] Lanier LL, Phillips JH, Hackett J, Tutt M, and Kumar V: Natural killer cells: definition of a cell type rather than a function. $J$ Immunol 1986, 137:2735-2739.

[6] O’Sullivan TE, Sun JC, and Lanier LL: Natural Killer Cell Memory. Immunity 2015, 43:634-645.

[7] Cerwenka A and Lanier LL: Natural killer cell memory in infection, inflammation and cancer. Nat Rev Immunol 2016, 16:112-123.

[8] O'Leary JG, Goodarzi M, Drayton DL, and von Andrian UH: T cell- and B cellindependent adaptive immunity mediated by natural killer cells. Nat Immunol 2006, 7:507-516.

[9] Paust S, Gill HS, Wang BZ, Flynn MP, Moseman EA, Senman B, Szczepanik M, Telenti A, Askenase PW, Compans RW, and von Andrian UH: Critical role for the chemokine receptor CXCR6 in NK cell-mediated antigen-specific memory of haptens and viruses. Nat Immunol 2010, 11:1127-1135. 
[10] Cooper MA, Elliott JM, Keyel PA, Yang L, Carrero JA, and Yokoyama WM: Cytokineinduced memory-like natural killer cells. Proc Natl Acad Sci USA 2009, 106:1915-1919.

[11] Prlic M, Blazar BR, Farrar MA, and Jameson SC: In vivo survival and homeostatic proliferation of natural killer cells. J Exp Med 2003, 197:967-976.

$[12]^{* *}$ Nabekura T and Lanier LL: Antigen-specific expansion and differentiation of natural killer cells by alloantigen stimulation. $J$ Exp Med 2014, 211:2455-2465.

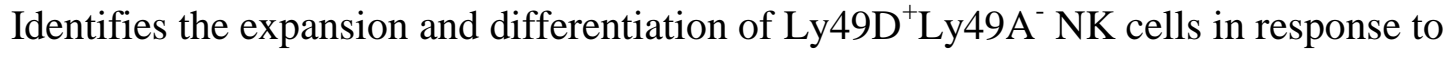
alloantigen stimulation.

[13] Sun JC, Beilke JN, and Lanier LL: Adaptive immune features of natural killer cells. Nature 2009, 457:557-561.

[14] Hendricks DW, Min-Oo G, and Lanier LL: Sweet Is the Memory of Past Troubles: NK Cells Remember. Curr Top Microbiol Immunol 2016, 395:147-171.

[15] Arase H, Mocarski ES, Campbell AE, Hill AB, and Lanier LL: Direct recognition of cytomegalovirus by activating and inhibitory NK cell receptors. Science 2002, 296:1323-1326.

[16] Daniels KA, Devora G, Lai WC, O’Donnell CL, Bennett M, and Welsh RM: Murine cytomegalovirus is regulated by a discrete subset of natural killer cells reactive with monoclonal antibody to Ly49H. J Exp Med 2001, 194:29-44.

[17] Smith HRC, Heusel JW, Mehta IK, Kim S, Dorner BG, Naidenko OV, Iizuka K, Furukawa H, Beckman DL, Pingel JT, et al.: Recognition of a virus-encoded ligand by a natural killer cell activation receptor. Proc Natl Acad Sci USA 2002, 99:8826-8831. 
[18]** Min-Oo G and Lanier LL: Cytomegalovirus generates long-lived antigen-specific NK cells with diminished bystander activation to heterologous infection. J Exp Med 2014, 211:2669-2680.

Demonstrates the antigen specificity of MCMV-induced Ly $49 \mathrm{H}^{+}$memory NK cells.

[19] ** Forbes CA, Scalzo AA, Degli-Esposti MA, and Coudert JD: Ly49C-dependent control of MCMV Infection by NK cells is cis-regulated by MHC Class I molecules. PLoS Pathog 2014, 10:e1004161.

With Ref. [20**] demonstrates that Ly49C restricts NK cell control of MCMV.

[20]** Forbes CA, Scalzo AA, Degli-Esposti MA, and Coudert JD: Ly49C Impairs NK Cell Memory in Mouse Cytomegalovirus Infection. J Immunol 2016, 197:128-140.

With Ref. [19**] demonstrates that Ly49C restricts NK cell control of MCMV.

[21]** Rahim MMA, Wight A, Mahmoud AB, Aguilar OA, Lee SH, Vidal SM, Carlyle JR, and Makrigiannis AP: Expansion and Protection by a Virus-Specific NK Cell Subset Lacking Expression of the Inhibitory NKR-P1B Receptor during Murine Cytomegalovirus Infection. J Immunol 2016, 197:2325-2337.

Demonstrates that co-expression of NKR-P1B on Ly49H+ NK cells restrict MCMV control.

[22] Abdul-Careem MF, Lee AJ, Pek EA, Gill N, Gillgrass AE, Chew MV, Reid S, and Ashkar AA: Genital HSV-2 infection induces short-term NK cell memory. PloS One 2012, 7:e32821.

[23] Gillard GO, Bivas-Benita M, Hovav AH, Grandpre LE, Panas MW, Seaman MS, Haynes BF, and Letvin NK: Thy1+ NK cells from vaccinia virus-primed mice confer protection against vaccinia virus challenge in the absence of adaptive lymphocytes. PLoS Pathog 2011, 7:e1002141. 
[24] van Helden MJG, Zaiss DMW, and Sijts AJAM: CCR2 defines a distinct population of NK cells and mediates their migration during influenza virus infection in mice. PloS One 2012, 7:e52027.

[25]* Reeves RK, Li H, Jost S, Blass E, Li H, Schafer JL, Varner V, Manickam C, Eslamizar L, Altfeld M, et al.: Antigen-specific NK cell memory in rhesus macaques. Nat Immunol 2015, 16:927-932.

Demonstrates the persistence of SIV-specific memory NK cells from vaccination and viral infection.

[26] Giavedoni LD, Velasquillo MC, Parodi LM, Hubbard GB, and Hodara VL: Cytokine expression, natural killer cell activation, and phenotypic changes in lymphoid cells from rhesus macaques during acute infection with pathogenic simian immunodeficiency virus. $J$ Virol 2000, 74:1648-1657.

[27] Gumá M, Angulo A, Vilches C, Gómez-Lozano N, Malats N, and López-Botet M: Imprint of human cytomegalovirus infection on the NK cell receptor repertoire. Blood 2004, 104:3664-3671.

[28] Gumá M, Budt M, Sáez A, Brckalo T, Hengel H, Angulo A, and López-Botet M:

Expansion of CD94/NKG2C+ NK cells in response to human cytomegalovirus-infected fibroblasts. Blood 2006, 107:3624-3631.

[29] Lopez-Vergès S, Milush JM, Schwartz BS, Pando MJ, Jarjoura J, York VA, Houchins JP, Miller S, Kang SM, Norris PJ, et al.: Expansion of a unique CD57 ${ }^{+}$NKG2Chi natural killer cell subset during acute human cytomegalovirus infection. Proc Natl Acad Sci USA 2011, 108:14725-14732. 
[30] Petitdemange C, Becquart P, Wauquier N, Béziat V, Debré P, Leroy EM, and Vieillard V: Unconventional repertoire profile is imprinted during acute chikungunya infection for natural killer cells polarization toward cytotoxicity. PLoS Pathog 2011, 7:e1002268.

[31] Béziat V, Dalgard O, Asselah T, Halfon P, Bedossa P, Boudifa A, Hervier B, Theodorou I, Martinot M, Debré $\mathrm{P}$, et al.: CMV drives clonal expansion of NKG2C+ NK cells expressing self-specific KIRs in chronic hepatitis patients. Eur J Immunol 2012, 42:447457.

[32] Saghafian-Hedengren S, Sohlberg E, Theorell J, Carvalho-Queiroz C, Nagy N, Persson JO, Nilsson C, Bryceson YT, and Sverremark-Ekström E: Epstein-Barr virus coinfection in children boosts cytomegalovirus-induced differentiation of natural killer cells. J Virol 2013, 87:13446-13455.

[33] Björkström NK, Lindgren T, Stoltz M, Fauriat C, Braun M, Evander M, Michä̈lsson J, Malmberg KJ, Klingström J, Ahlm C, and Ljunggren HG: Rapid expansion and longterm persistence of elevated NK cell numbers in humans infected with hantavirus. $J$ Exp Med 2011, 208:13-21.

[34] Björkström NK, Svensson A, Malmberg KJ, Eriksson K, and Ljunggren HG: Characterization of natural killer cell phenotype and function during recurrent human HSV-2 infection. PloS One 2011, 6:e27664.

[35]** Hendricks DW, Balfour HH, Dunmire SK, Schmeling DO, Hogquist KA, and Lanier LL: Cutting edge: NKG2C(hi)CD57+ NK cells respond specifically to acute infection with cytomegalovirus and not Epstein-Barr virus. J Immunol 2014, 192:4492-4496.

Demonstrates the specificity of $\mathrm{HCMV}$-induced $\mathrm{NKG}_{2} \mathrm{C}^{+}$memory NK cells. 
[36]* Djaoud Z, Riou R, Gavlovsky PJ, Mehlal S, Bressollette C, Gérard N, Gagne K, Charreau B, and Retière C: Cytomegalovirus-Infected Primary Endothelial Cells Trigger NKG2C+ Natural Killer Cells. J Innate Immun 2016, 8:374-385.

Demonstrates that degranulation of $\mathrm{NKG}_{2} \mathrm{C}^{+} \mathrm{NK}$ cells is triggered by co-culture with HCMVinfected primary human endothelial cells.

[37] Rölle A, Pollmann J, Ewen EM, Le VTK, Halenius A, Hengel H, and Cerwenka A: IL-12producing monocytes and HLA-E control HCMV-driven NKG2C+ NK cell expansion. J Clin Invest 2014, 124:5305-5316.

[38]** Liu LL, Landskron J, Ask EH, Enqvist M, Sohlberg E, Traherne JA, Hammer Q, J. Goodridge JP, Larsson S, Jayaraman J, et al.: Critical Role of CD2 Co-stimulation in Adaptive Natural Killer Cell Responses Revealed in NKG2C-Deficient Humans. Cell Rep 2016, 15:1088-1099.

With Ref. [39**] identifies synergy of CD2- and CD16-mediated NK cell activation in HCMV infection.

[39]** Rölle A, Halenius A, Ewen EM, Cerwenka A, Hengel H, and Momburg F: CD2-CD58 interactions are pivotal for the activation and function of adaptive natural killer cells in human cytomegalovirus infection. Eur J Immunol 2016, DOI: 10.1002/eji.201646492 With Ref. [38**] identifies synergy of CD2- and CD16-mediated NK cell activation in HCMV infection.

[40] Rölle A and Brodin P: Immune Adaptation to Environmental Influence: The Case of NK Cells and HCMV. Trends Immunol 2016, 37:233-243.

[41] Mócsai A: Diverse novel functions of neutrophils in immunity, inflammation, and beyond. $J$ Exp Med 2013, 210:1283-1299. 
[42] Scapini P and Cassatella MA: Social networking of human neutrophils within the immune system. Blood 2014, 124:710-719.

[43] Costantini C, Micheletti A, Calzetti F, Perbellini O, Pizzolo G, and Cassatella MA: Neutrophil activation and survival are modulated by interaction with NK cells. Int Immunol 2010, 22:827-838.

[44] Thorén FB, Riise RE, Ousbäck J, Della Chiesa M, Alsterholm M, Marcenaro E, Pesce S, Prato C, Cantoni C, Bylund J, et al.: Human NK Cells induce neutrophil apoptosis via an NKp46- and Fas-dependent mechanism. J Immunol 2012, 188:1668-1674.

[45] Stacey MA, Marsden M, Pham N TA, Clare S, Dolton G, Stack G, Jones E, Klenerman P, Gallimore AM, Taylor PR, et al.: Neutrophils recruited by IL-22 in peripheral tissues function as TRAIL-dependent antiviral effectors against MCMV. Cell Host Microbe 2014, 15:471-483.

[46] Jaeger BN, Donadieu J, Cognet C, Bernat C, Ordoñez-Rueda D, Barlogis V, Mahlaoui N, Fenis A, Narni-Mancinelli E, Beaupain B, et al.: Neutrophil depletion impairs natural killer cell maturation, function, and homeostasis. J Exp Med 2012, 209:565-580. [47]** Riise RE, Bernson E, Aurelius J, Martner A, Pesce S, Della Chiesa M, Marcenaro E, Bylund J, Hellstrand K, Moretta L, et al.: TLR-Stimulated Neutrophils Instruct NK Cells To Trigger Dendritic Cell Maturation and Promote Adaptive T Cell Responses. J Immunol 2015, 195:1121-1128.

Illustrates the interaction between neutrophils and NK cells in coordinating an immune response.

[48]* Pliyev BK, Kalintseva MV, Abdulaeva SV, Yarygin KN, and Savchenko VG:

Neutrophil microparticles modulate cytokine production by natural killer cells. Cytokine 2014, 65:126-129. 
Demonstrates the effects of neutrophil microparticles on NK cells to produce anti-inflammatory cytokines.

[49]* Amano K, Hirayama M, Azuma E, Iwamoto S, Keida Y, and Komada Y: Neutrophils induced licensing of natural killer cells. Mediators Inflamm 2015, DOI: $10.1155 / 2015 / 747680$.

Demonstrates the promotion of NK cell licensing by neutrophils.

[50] Michel T, Hentges F, and Zimmer J: Consequences of the crosstalk between monocytes/macrophages and natural killer cells. Front Immunol 2012, DOI: 10.3389/fimmu.2012.00403

[51] Romo N, Magri G, Muntasell A, Heredia G, Baía D, Angulo A, Guma M, and López-Botet M: Natural killer cell-mediated response to human cytomegalovirus-infected macrophages is modulated by their functional polarization. J Leukoc Biol 2011, 90:717-726.

[52] Bellora F, Castriconi R, Dondero A, Reggiardo G, Moretta L, Mantovani A, Moretta A, and Bottino C: The interaction of human natural killer cells with either unpolarized or polarized macrophages results in different functional outcomes. Proc Natl Acad Sci USA 2010, 107:21659-21664.

[53]** Lenac Rovis T, Kucan Brlic P, Kaynan N, Juranic Lisnic V, Brizic I, Jordan S, Tomic A, Kvestak D, Babic M, Tsukerman P, et al.: Inflammatory monocytes and NK cells play a crucial role in DNAM-1-dependent control of cytomegalovirus infection. $J$ Exp Med 2016, 213:1835-1850.

Identifies DNAM-1 as a critical component of monocyte and NK cell interactions during MCMV infection. 
[54]* Quillay H, El Costa H, Duriez M, Marlin R, Cannou C, Madec Y, de Truchis C, Rahmati M, Barré-Sinoussi F, Nugeyre MT, and Menu E: NK cells control HIV-1 infection of macrophages through soluble factors and cellular contacts in the human decidua. Retrovirology 2016, DOI: 10.1186/s12977-016-0271-z

Demonstrates control of HIV-1 in decidual macrophages by NK cells.

[55] Ferlazzo G, Pack M, Thomas D, Paludan C, Schmid D, Strowig T, Bougras G, Muller WA, Moretta L, and Münz C: Distinct roles of IL-12 and IL-15 in human natural killer cell activation by dendritic cells from secondary lymphoid organs. Proc Natl Acad Sci USA 2004, 101:16606-16611.

[56] Vitale M, Della Chiesa M, Carlomagno S, Romagnani C, Thiel A, Moretta L, and Moretta A: The small subset of CD56brightCD16- natural killer cells is selectively responsible for both cell proliferation and interferon-gamma production upon interaction with dendritic cells. Eur J Immunol 2004, 34:1715-1722.

[57] Vitale M, Della Chiesa M, Carlomagno S, Pende D, Aricò M, Moretta L, and Moretta A: NK-dependent DC maturation is mediated by TNFalpha and IFNgamma released upon engagement of the NKp30 triggering receptor. Blood 2005, 106:566-571.

[58] Mortier E, Woo T, Advincula R, Gozalo A, and Ma A: IL-15Ralpha chaperones IL-15 to stable dendritic cell membrane complexes that activate NK cells via trans presentation. $J$ Exp Med 2008, 205:1213-1225.

[59] Moretta A: Natural killer cells and dendritic cells: rendezvous in abused tissues. Nat Rev Immunol 2002, 2:957-964.

[60] Fehniger TA, Cooper MA, Nuovo GJ, Cella M, Facchetti F, Colonna M, and Caligiuri MA: CD56bright natural killer cells are present in human lymph nodes and are activated 
by $T$ cell-derived IL-2: a potential new link between adaptive and innate immunity. Blood 2003, 101:3052-3057.

[61] Martín-Fontecha A, Thomsen LL, Brett S, Gerard C, Lipp M, Lanzavecchia A, and Sallusto F: Induced recruitment of NK cells to lymph nodes provides IFN-gamma for $\mathbf{T}(\mathrm{H}) 1$ priming. Nat Immunol 2004, 5:1260-1265.

[62]* Lawler C, Tan CSE, Simas JP, and Stevenson PG: Type 1 interferons and NK cells restrict gamma-herpesvirus lymph node infection. $J$ Virol 2016, DOI: 10.1128/JVI.01108-16

Illustrates the importance of NK cell recruitment to the lymph node during viral infection.

[63] Mailliard RB, Son YI, Redlinger R, Coates PT, Giermasz A, Morel PA, Storkus WJ, and Kalinski P: Dendritic cells mediate NK cell help for Th1 and CTL responses: twosignal requirement for the induction of NK cell helper function. J Immunol 2003, 171:2366-2373.

[64] Morandi B, Bougras G, Muller WA, Ferlazzo G, and Münz C: NK cells of human secondary lymphoid tissues enhance $\mathbf{T}$ cell polarization via IFN-gamma secretion. Eur J Immunol 2006, 36:2394-2400.

[65] Gerosa F, Baldani-Guerra B, Nisii C, Marchesini V, Carra G, and Trinchieri G: Reciprocal activating interaction between natural killer cells and dendritic cells. $J$ Exp Med 2002, 195:327-333.

[66] Goldszmid RS, Caspar P, Rivollier A, White S, Dzutsev A, Hieny S, Kelsall B, Trinchieri G, and Sher A: NK cell-derived interferon- $\gamma$ orchestrates cellular dynamics and the differentiation of monocytes into dendritic cells at the site of infection. Immunity 2012, 36:1047-1059. 
[67]** Vogel K, Thomann S, Vogel B, Schuster P, and Schmidt B: Both plasmacytoid dendritic cells and monocytes stimulate natural killer cells early during human herpes simplex virus type 1 infections. Immunology 2014, 143:588-600.

With Ref. [68] demonstrates NK cell activation by herpes simplex virus-exposed dendritic cells.

[68] Swiecki M, Wang Y, Gilfillan S, and Colonna M: Plasmacytoid dendritic cells contribute to systemic but not local antiviral responses to HSV infections. PLoS Pathog 2013, 9:e1003728.

[69]* Brandstadter JD, Huang X, and Yang Y: NK cell-extrinsic IL-18 signaling is required for efficient NK-cell activation by vaccinia virus. Eur J Immunol 2014, 44:2659-2666.

Demonstrates IL-18 signaling and NKG2D engagement from dendritic cells are required for NK cell-mediated control of vaccinia virus.

[70]* Moreno-Nieves UY, Didier C, Lévy Y, Barré-Sinoussi F, Scott-Algara D, and ANRS HIV Vaccine Network (AHVN): NK cells are primed by ANRS MVA(HIV)-infected DCs, via a mechanism involving NKG2D and membrane-bound IL-15, to control HIV-1 infection in CD4+ T cells. Eur J Immunol 2014, 44:2370-2379.

Demonstrates activation of NK cells with HIV-1-infected dendritic cells requires IL-15 signaling and NKG2D engagement.

[71] Chang MO, Suzuki T, Suzuki H, and Takaku H: HIV-1 Gag-virus-like particles induce natural killer cell immune responses via activation and maturation of dendritic cells. $J$ Innate Immun 2012, 4:187-200.

[72] Pende D, Castriconi R, Romagnani P, Spaggiari GM, Marcenaro S, Dondero A, Lazzeri E, Lasagni L, Martini S, River P, et al.: Expression of the DNAM-1 ligands, Nectin-2 
(CD112) and poliovirus receptor (CD155), on dendritic cells: relevance for natural killer-dendritic cell interaction. Blood 2006, 107:2030-2036.

[73]* Smith LE, Olszewski MA, Georgoudaki AM, Wagner AK, Hägglöf T, Karlsson MCI, Dominguez-Villar M, Garcia-Cozar F, Mueller S, Ravens I, et al.: Sensitivity of dendritic cells to NK-mediated lysis depends on the inflammatory environment and is modulated by CD54/CD226-driven interactions. J Leukoc Biol 2016, DOI: 10.1189/jlb.3A0615-271RR

Demonstrates lysis of GM-CSF activated dendritic cells by NK cells is mediated by DNAM-1 and LFA-1.

[74] Elboim M, Grodzovski I, Djian E, Wolf DG, and Mandelboim O: HSV-2 specifically down regulates HLA-C expression to render HSV-2-infected DCs susceptible to NK cell killing. PLoS Pathog 2013, 9:e1003226.

[75]* Lim DSL, Yawata N, Selva KJ, Li N, Tsai CY, Yeong LH, Liong KH, Ooi EE, Chong NK, Ng ML, et al.: The combination of type I IFN, TNF- $\alpha$, and cell surface receptor engagement with dendritic cells enables NK cells to overcome immune evasion by dengue virus. J Immunol 2014, 193:5065-5075.

Demonstrates cytokine- and contact-dependent interactions between dendritic cells and NK cells in response to Dengue virus infection.

[76] Martinet J, Dufeu-Duchesne T, Bruder Costa J, Larrat S, Marlu A, Leroy V, Plumas J, and Aspord C: Altered functions of plasmacytoid dendritic cells and reduced cytolytic activity of natural killer cells in patients with chronic HBV infection. Gastroenterology 2012, 143:1586-1596. 
[77] Tjwa ETTL, van Oord GW, Biesta PJ, Boonstra A, Janssen HLA, and Woltman AM: Restoration of TLR3-activated myeloid dendritic cell activity leads to improved natural killer cell function in chronic hepatitis B virus infection. J Virol 2012, 86:41024109.

[78] Mandaric S, Walton SM, Rülicke T, Richter K, Girard-Madoux MJH, Clausen BE, Zurunic A, Kamanaka M, Flavell RA, Jonjic S, and Oxenius A: IL-10 suppression of NK/DC crosstalk leads to poor priming of MCMV-specific CD4 T cells and prolonged MCMV persistence. PLoS Pathog 2012, 8:e1002846.

[79]** Ellegård R, Crisci E, Andersson J, Shankar EM, Nyström S, Hinkula J, and Larsson M: Impaired NK Cell Activation and Chemotaxis toward Dendritic Cells Exposed to Complement-Opsonized HIV-1. J Immunol 2015, 195:1698-1704.

Illustrates impaired NK cell recruitment by dendritic cells exposed to complement-opsonized HIV-1 virus.

[80] Su HC, Nguyen KB, Salazar-Mather TP, Ruzek MC, Dalod MY, and Biron CA: NK cell functions restrain T cell responses during viral infections. Eur J Immunol 2001, 31:3048-3055.

[81] Krebs P, Barnes MJ, Lampe K, Whitley K, Bahjat KS, Beutler B, Janssen E, and Hoebe K: NK-cell-mediated killing of target cells triggers robust antigen-specific T-cellmediated and humoral responses. Blood 2009, 113:6593-6602.

[82] Cook KD, Waggoner SN, and Whitmire JK: NK cells and their ability to modulate $\mathbf{T}$ cells during virus infections. Crit Rev Immunol 2014, 34:359-388.

[83] Waggoner SN, Cornberg M, Selin LK, and Welsh RM: Natural killer cells act as rheostats modulating antiviral T cells. Nature 2012, 481:394-398. 
[84]* Waggoner SN, Daniels KA, and Welsh RM: Therapeutic depletion of natural killer cells controls persistent infection. J Virol 2014, 88:1953-1960.

With Ref. [83, 86, and 87**] demonstrates dual functions of NK cells in controlling T cell responses in lymphocytic choriomeningitis virus infection.

[85]** Stelekati E, Shin H, Doering TA, Dolfi DV, Ziegler CG, Beiting DP, Dawson L, Liboon J, Wolski D, Ali MAA, et al.: Bystander chronic infection negatively impacts development of CD8(+) T cell memory. Immunity 2014, 40:801-813.

Demonstrates the impairment of memory $\mathrm{CD}^{+} \mathrm{T}$ cell generation due to chronic lymphocytic choriomeningitis virus infection.

[86] Cook KD and Whitmire JK: The depletion of NK cells prevents $\mathbf{T}$ cell exhaustion to efficiently control disseminating virus infection. J Immunol 2013, 190:641-649.

[87]** Cook KD, Kline HC, and Whitmire JK: NK cells inhibit humoral immunity by reducing the abundance of CD4+ T follicular helper cells during a chronic virus infection. J Leukoc Biol 2015, 98:153-162.

With Ref. [83, 84*, and 86] demonstrates dual functions of NK cells in controlling T cell responses in lymphocytic choriomeningitis virus infection.

[88]* Crouse J, Bedenikovic G, Wiesel M, Ibberson M, Xenarios I, Von Laer D, Kalinke U, Vivier E, Jonjic S, and Oxenius A: Type I interferons protect $\mathbf{T}$ cells against $\mathbf{N K}$ cell attack mediated by the activating receptor NCR1. Immunity 2014, 40:961-973.

Demonstrates interferon sensing by $\mathrm{CD}^{+} \mathrm{T}$ cells protects against NK cells-mediated lysis.

[89] Ge MQ, Ho AWS, Tang Y, Wong KHS, Chua BYL, Gasser S, and Kemeny DM: NK cells regulate $\mathrm{CD8}+\mathrm{T}$ cell priming and dendritic cell migration during influenza $\mathrm{A}$ 
infection by IFN- $\gamma$ and perforin-dependent mechanisms. J Immunol 2012, 189:20992109.

[90] Abdul-Careem MF, Mian MF, Yue G, Gillgrass A, Chenoweth MJ, Barra NG, Chew MV, Chan T, Al-Garawi AA, Jordana M, and Ashkar AA: Critical role of natural killer cells in lung immunopathology during influenza infection in mice. J Infect Dis 2012, 206:167177.

[91] Kim M, Osborne NR, Zeng W, Donaghy H, McKinnon K, Jackson DC, and Cunningham AL: Herpes simplex virus antigens directly activate NK cells via TLR2, thus facilitating their presentation to CD4 T lymphocytes. J Immunol 2012, 188:4158-4170.

[92]** Loyon R, Picard E, Mauvais O, Queiroz L, Mougey V, Pallandre JR, Galaine J, MercierLetondal P, Kellerman G, Chaput N, et al:: IL-21-Induced MHC Class II+ NK Cells Promote the Expansion of Human Uncommitted CD4+ Central Memory T Cells in a Macrophage Migration Inhibitory Factor-Dependent Manner. J Immunol 2016, 197:85-96.

Demonstrates that IL-21 induces a subset of NK cells to modulate the development of central memory $\mathrm{CD} 4^{+} \mathrm{T}$ cells.

[93] Vargas-Inchaustegui DA, Xiao P, Tuero I, Patterson LJ, and Robert-Guroff M: NK and CD4+ $T$ cell cooperative immune responses correlate with control of disease in a macaque simian immunodeficiency virus infection model. J Immunol 2012, 189:18781885.

[94]** Garcia-Beltran WF, Hölzemer A, Martrus G, Chung AW, Pacheco Y, Simoneau CR, Rucevic M, Lamothe-Molina PA, Pertel T, Kim TE, et al.: Open conformers of HLA-F 
are high-affinity ligands of the activating NK-cell receptor KIR3DS1. Nat Immunol 2016, 17:1067-1074.

Demonstrates that KIR3DS1 binds to HLA-F on HIV-1-infected $\mathrm{CD} 4^{+} \mathrm{T}$ cells to induce NK cell effector functions.

[95] Mitrović M, Arapović J, Jordan S, Fodil-Cornu N, Ebert S, Vidal SM, Krmpotić A, Reddehase MJ, and Jonjić S: The NK cell response to mouse cytomegalovirus infection affects the level and kinetics of the early CD8(+) T-cell response. J Virol 2012, 86:21652175.

[96]* Zheng M, Sun R, Wei H, and Tian Z: NK Cells Help Induce Anti-Hepatitis B Virus CD8+ T Cell Immunity in Mice. J Immunol 2016, 196:4122-4131.

Describes a mouse model of hepatitis B infection where there is a positive correlation between HBV-specific $\mathrm{CD} 8^{+} \mathrm{T}$ cells and NK cells.

[97]* Bayard C, Lepetitcorps H, Roux A, Larsen M, Fastenackels A, Salle V, Vieillard V, Marchant A, Stern M, Boddaert J, et al.: Coordinated expansion of both memory T cells and NK cells in response to CMV infection in humans. Eur J Immunol 2016, 46:11681179.

Describes a human study where age positively correlates with increased percentages of $\mathrm{NKG}_{2} \mathrm{C}^{+}$ NK cells and $\mathrm{CD}^{+} \mathrm{T}$ cells. 
Table 1: Interactions of NK cells with other immune cells

Table specifies the experimental model and the effects of the interactions

\begin{tabular}{|c|c|c|c|}
\hline NK cell cross talk with: & Interaction & Experimental Model & Reference \\
\hline \multirow[t]{3}{*}{ Neutrophils } & NKp46 and Fas-mediated apoptosis of neutrophils & $\begin{array}{l}\text { Human PBMC co-culture } \\
\text { Aseptic inflammation }\end{array}$ & 44 \\
\hline & $\begin{array}{l}\mathrm{IL}-22 \text { from } \mathrm{T}, \mathrm{CD}^{+} \mathrm{NK} 1.1^{+} \mathrm{T} \text {, and } \mathrm{CD}^{-} \mathrm{NK} 1.1^{+} \text {cells } \\
\text { mediated neutrophil recruitment into infected areas }\end{array}$ & Mouse cytomegalovirus & 45 \\
\hline & $\begin{array}{l}\text { TLR-activated neutrophils secreted chemokines and } \\
\text { ROS to recruit and activate NK cells } \\
\text { IL- } 8, \text { IL-1 } \beta \text {, and IL- } 18 \text { conditioning of NK cells } \\
\text { induced } \\
\text { DC maturation and CD4 } 4^{+} \text {T cell activation }\end{array}$ & $\begin{array}{l}\text { Human PBMC co-culture } \\
\text { TLR stimulations }\end{array}$ & 47 \\
\hline \multirow[t]{4}{*}{$\begin{array}{l}\text { Macrophages/ } \\
\text { monocytes }\end{array}$} & $\begin{array}{l}\text { M1 induced NK cells to secrete IFN- } \gamma \\
\text { NKp46-, DNAM-1-, 2B4-mediated degranulation }\end{array}$ & $\begin{array}{l}\text { Human PBMC co-culture } \\
\text { Human cytomegalovirus }\end{array}$ & 51 \\
\hline & $\begin{array}{l}\text { IL-12-activated NK lyse M2 readily } \\
\text { M1 induced NK cells to secrete IFN- } \gamma \\
\text { NKp46 induced cytotoxicity } \\
\text { 2B4-induced IFN- } \gamma \\
\text { DNAM-1-induced both }\end{array}$ & $\begin{array}{l}\text { Human PBMC co-culture } \\
\text { LPS or bacillus Calmette-Guérin }\end{array}$ & 52 \\
\hline & $\begin{array}{l}\text { DNAM-1 and CD155 control infection } \\
\text { CCL2 and iNOS production by monocytes }\end{array}$ & Mouse cytomegalovirus & 53 \\
\hline & $\begin{array}{l}\text { Cell contact required - unknown receptors } \\
\text { Unknown soluble factor }\end{array}$ & Human immunodeficiency virus & 54 \\
\hline \multirow[t]{9}{*}{ Dendritic cells } & $\begin{array}{l}\text { IFN- } \alpha \text { and TNF- } \alpha \text { from DCs promoted NK cell } \\
\text { degranulation and IFN- } \gamma \text { production }\end{array}$ & $\begin{array}{l}\text { Human PBMC co-culture and } \\
\text { mouse model of herpes simplex virus }\end{array}$ & $\begin{array}{l}67 \\
68 \\
\end{array}$ \\
\hline & $\begin{array}{l}\text { IL-18 signaling induced Rae-1 expression on DC } \\
\text { NK cells required IL-18 and NKG2D ligation for } \\
\text { activation }\end{array}$ & Mouse Vaccinia & 69 \\
\hline & $\begin{array}{l}\text { DC-derived IL-15 and NKG2D ligands are necessary } \\
\text { for NK cell } \\
\text { activation to control HIV-infected } \mathrm{CD} 4^{+} \mathrm{T} \text { cells }\end{array}$ & $\begin{array}{l}\text { Human PBMC co-culture } \\
\text { Human immunodeficiency virus }\end{array}$ & 70 \\
\hline & $\begin{array}{l}\text { Gag-VLPs induced DC cytokines that activated } \\
\text { NK cells to lyse HIV-infected } \mathrm{CD}^{+} \mathrm{T} \text { cells }\end{array}$ & $\begin{array}{l}\text { Human PBMC co-culture and } \\
\text { mouse model of human } \\
\text { immunodeficiency virus }\end{array}$ & 71 \\
\hline & $\begin{array}{l}\text { HSV-2 viral protein ICP47 mediated downregulation } \\
\text { of HLA-C on infected cells resulting in NK cell lysis }\end{array}$ & $\begin{array}{l}\text { Human PBMC co-culture } \\
\text { Herpes simplex virus }\end{array}$ & 74 \\
\hline & $\begin{array}{l}\text { Infected DCs downregulated HLA class I and } \\
\text { secreted type I IFN and TNF- } \alpha \text { to induce NK cell } \\
\text { lysis and IFN- } \gamma \text { production } \\
\text { NK cell killing via Fas-FasL and perforin-granzyme }\end{array}$ & $\begin{array}{l}\text { Human PBMC co-culture } \\
\text { Dengue virus }\end{array}$ & 75 \\
\hline & $\begin{array}{l}\text { TLR9-matured DCs poorly activated NK cells due to } \\
\text { decreased IFN- } \alpha \text { and OX40L expression }\end{array}$ & \multirow[t]{2}{*}{$\begin{array}{l}\text { Human PBMC co-culture from } \\
\text { chronic hepatitis B virus patients }\end{array}$} & 76 \\
\hline & Matured DCs poorly activated NK cells & & 77 \\
\hline & $\begin{array}{l}\text { IL-10 suppressed cross talk and NK priming of } \\
\mathrm{CD} 4^{+} \mathrm{T} \text { cells }\end{array}$ & Mouse cytomegalovirus & 78 \\
\hline
\end{tabular}




\begin{tabular}{|c|c|c|c|}
\hline & NKG2D- and NKp46 mediated cross talk & & \\
\hline & $\begin{array}{l}\text { HIV exposed-DCs secreted CCL3 and CXCL10 } \\
\text { to recruit NK cells for effector functions }\end{array}$ & $\begin{array}{l}\text { Human PBMC co-culture } \\
\text { Human immunodeficiency virus }\end{array}$ & 79 \\
\hline \multirow[t]{6}{*}{ CD4+ T cells } & $\begin{array}{l}\text { NK cells lysed activated } \mathrm{CD}^{+} \mathrm{T} \text { cells via perforin } \\
\text { and not Fas or TNF }\end{array}$ & $\begin{array}{l}\text { Mouse lymphocytic choriomeningitis } \\
\text { virus }\end{array}$ & 84 \\
\hline & $\begin{array}{l}\text { CCL21 and CXCL10 from NK cells recruited } \\
\text { T cells to peripheral lymph nodes } \\
\text { Perforin-mediated apoptosis was necessary for } \\
\text { DC antigen uptake }\end{array}$ & Mouse model of influenza & 89 \\
\hline & $\begin{array}{l}\text { HSV-exposed NK cells upregulated HLA-DQ } \\
\text { and HLA-DR to form synapses with CD4+ T cells }\end{array}$ & $\begin{array}{l}\text { Human PBMC co-culture } \\
\text { Herpes simplex virus }\end{array}$ & 91 \\
\hline & $\begin{array}{l}\text { IL-21-activated NK cells produced macrophage } \\
\text { inhibitory factor to induce } \\
\text { differentiation of central memory } \mathrm{CD}^{+} \mathrm{T} \text { cells }\end{array}$ & $\begin{array}{l}\text { Mouse study } \\
\text { Human biopsies }\end{array}$ & 92 \\
\hline & $\begin{array}{l}\text { IL- } 2 \text { from antigen-specific } \mathrm{CD}^{+} \mathrm{T} \text { cells was } \\
\text { necessary for NK cell activation, IFN- } \gamma \text {, and } \\
\text { cytotoxicity }\end{array}$ & Simian immunodeficiency virus & 93 \\
\hline & $\begin{array}{l}\text { KIR3DS } 1^{+} \text {NK cells suppressed HIV-1 replication } \\
\text { in infected HLA-F-expressing CD } 4^{+} \mathrm{T} \text { cell }\end{array}$ & $\begin{array}{l}\text { Human PBMC co-culture } \\
\text { Human immunodeficiency virus }\end{array}$ & 94 \\
\hline
\end{tabular}


Figure 1: Expansion of NK cells in cytomegalovirus infection
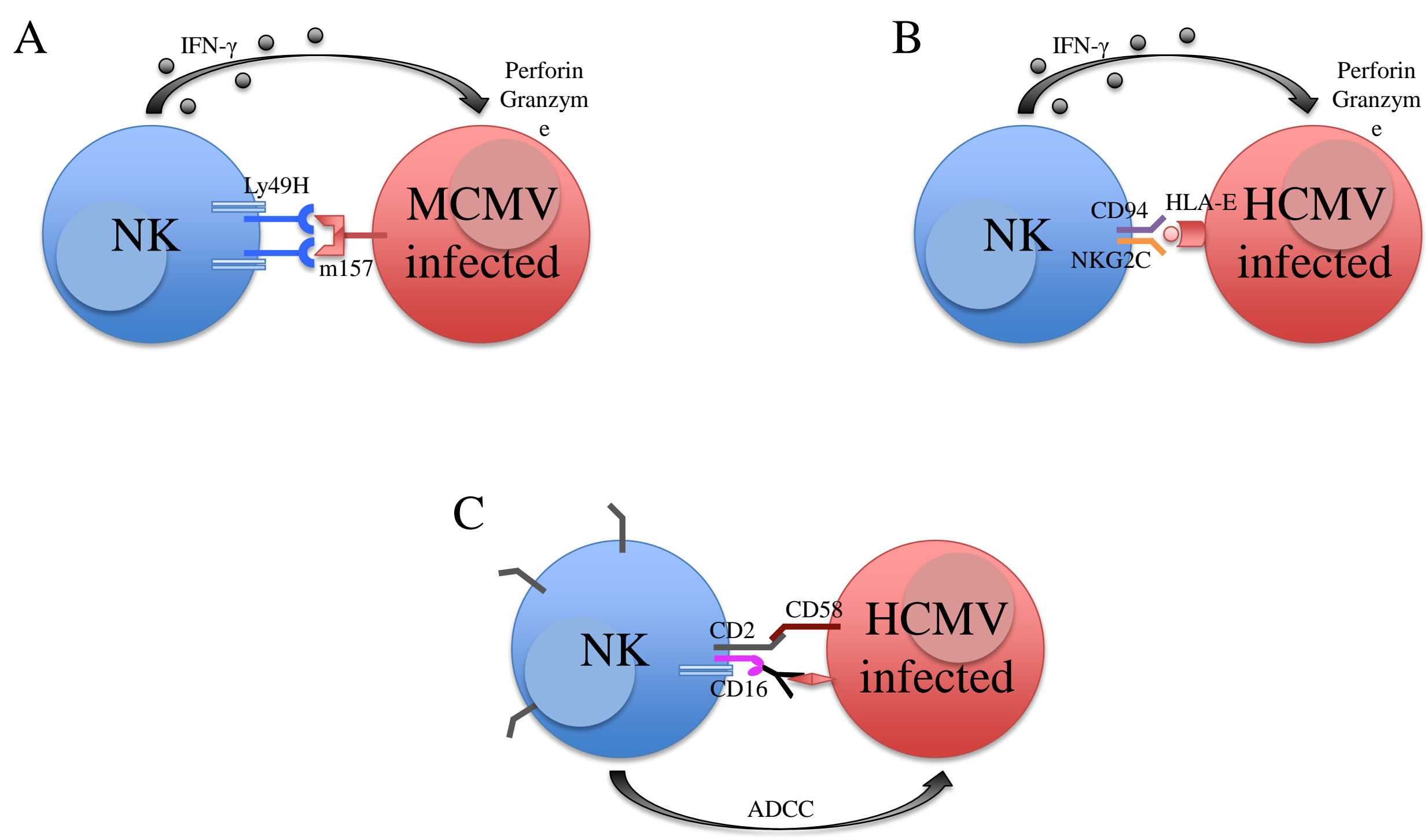
Figure 2: NK cell interactions and their effects on other immune cells

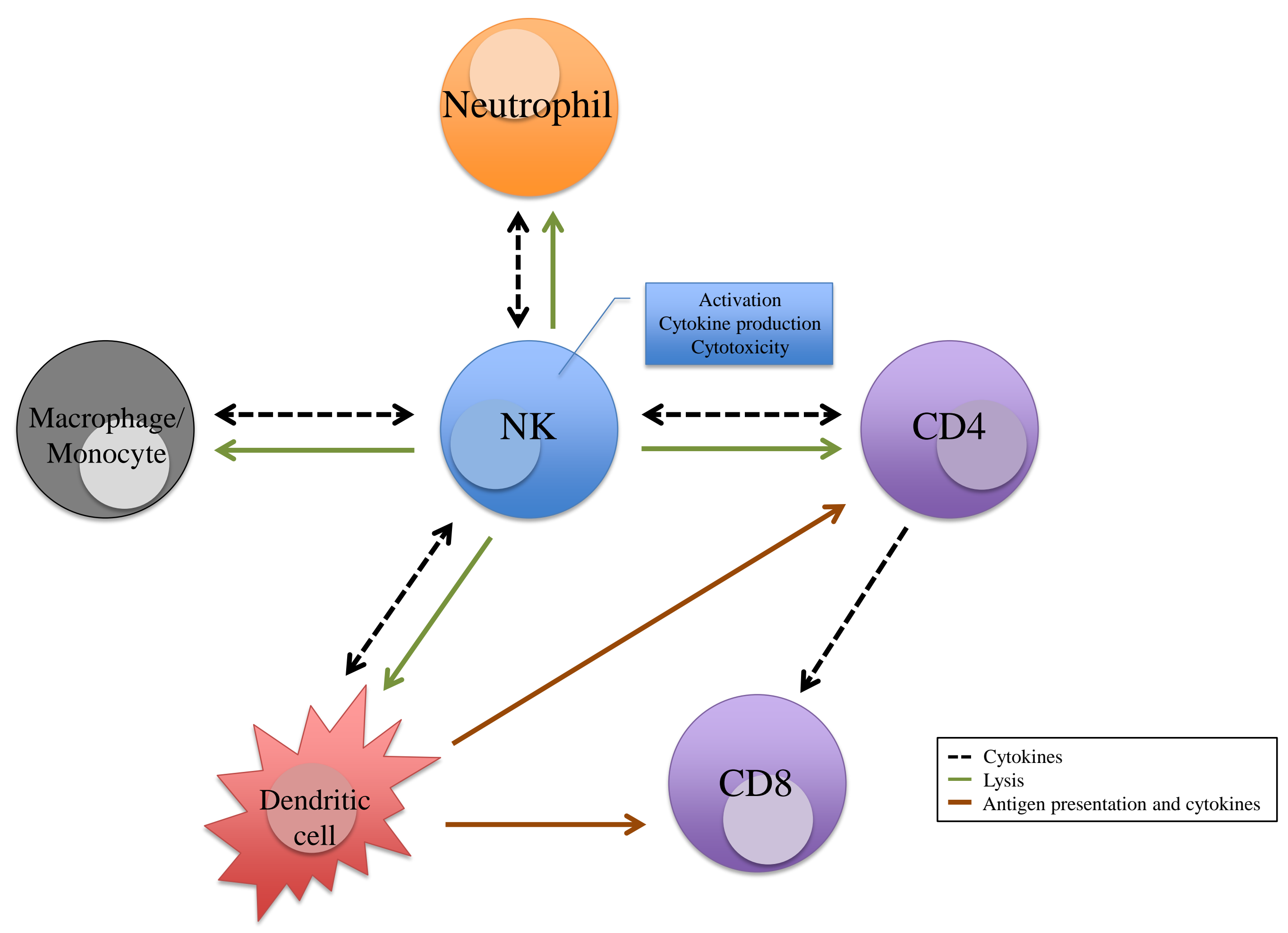

